Article

\title{
Triggers of Mass Atrocities
}

\author{
Scott Straus \\ Department of Political Science, University of Wisconsin-Madison, Madison, WI 53706, USA; E-Mail: sstraus@wisc.edu
}

Submitted: 13 June 2015 | In Revised Form: 5 August 2015 | Accepted: 7 August 2015 |

Published: 27 October 2015

\begin{abstract}
The concept of "triggers" enjoys wide usage in the atrocity prevention policymaking community. However, the concept has received limited academic analysis. This paper reviews the concept critically, develops a definition, and subjects the concept to empirical analysis. The paper offers a mild endorsement of the concept of triggers of atrocity. The paper identifies four main categories of triggering event but cautions that triggers cannot be separated from context or decision-makers.
\end{abstract}

\section{Keywords}

atrocity; mass atrocity; genocide; prevention; triggers

\section{Issue}

This article is part of the special issue "Mass Atrocity Prevention", edited by Professor Karen E. Smith (London School of Economics and Political Science, UK).

(C) 2015 by the author; licensee Cogitatio (Lisbon, Portugal). This article is licensed under a Creative Commons Attribution 4.0 International License (CC BY).

\section{Introduction}

In recent years, analysts have developed increasingly strong models for identifying risk factors of genocide and other mass atrocities, in particular concerning the macro-level drivers of such violence (Goldsmith, Butcher, Semenovich, \& Sowmya, 2013; Ulfelder \& Valentino, 2008; United Nations Office on Genocide Prevention and the Responsibility to Protect, 2014). ${ }^{1}$ However, less is known about the specific timing of when atrocities will start and what will make them start. The key question is: what shifts a country from being at risk of atrocities to atrocities beginning? ${ }^{2}$

To answer that question, analysts often employ the concept of "triggers," or specific events, occurrences,

\footnotetext{
${ }^{1}$ For a review of major categories of macro-level factors, see Straus (2012).

2 The paper uses the concepts of "genocide," "atrocities," and "mass atrocities" interchangeably. In general, the paper is looking to analyze a class of events in which large numbers of civilians are purposively killed. Such violence includes both groupselective deliberate killing, such as genocide, but also nongroup selective killing, such as crimes against humanity.
}

or tipping points that catalyze large-scale violence. Yet despite widespread usage of the term, in particular in policy, the concept has received limited scholarly attention and analysis. Indeed, some academics remain skeptical about the prospect of identifying specific triggers of atrocity. They worry that particular types of triggers do not have systematic effects on catalyzing atrocities; they emphasize the underlying conditions rather than specific categories of events.

The question has policymaking and theoretical relevance. On the policy side, understanding timing is crucial for better preparedness and for developing different approaches to prevention and timely response if atrocities begin. By the same token, understanding what ignites an atrocity crime could lead to new prevention measures-if the igniters can be defused then an atrocity crime may not take place. On the scholarly side, an inquiry into triggers has at least two areas of potential. First, a better understanding of the catalysts of atrocity may lead to new theoretical insights about the proximate drivers of atrocity. Second, studying triggers is an opportunity to adjudicate between competing theoretical models of genocide and mass atrocity. 
With those concerns in mind, this paper presents a social scientific inquiry into triggers of mass atrocity. The paper addresses three interrelated questions: first, what is a trigger of mass atrocity? Second, do specific categories of events have a systematic effect in starting or accelerating mass atrocity? Third, in light of the second question, does the analysis of triggers support or detract from any existing scholarship on the drivers of mass atrocity? To examine that question, the paper employs both conceptual analysis as well as an empirical analysis of a nonrandom sample of atrocity cases primarily since World War II.

The paper offers a mild endorsement of the concept of triggers. The paper finds that the effects of triggering events cannot be separated from their context or from the influential decision-makers who respond to the events. The same event often has quite different ramifications in different countries, which suggests that underlying risk conditions are most determinative for the outbreak of atrocities. Moreover, elites have some autonomy in setting in motion violence, which suggests that agency matters. Reactions to the events rather than only the events themselves are crucial. ${ }^{3}$ At the same time, the paper finds that, under those circumstances, certain events can and do have independent effects on catalyzing large-scale violence against civilians. The paper offers a definition that seeks to capture these elements.

Empirically, the paper finds that the triggers most commonly associated with catalyzing mass violence concern changes to the strategic environment, which in turn lends support to strategic theories of genocide and mass atrocity. ${ }^{4}$ Within the sample of cases, battlefield changes, assassinations, and territorial takeovers are those events that are most consistently associated with large increases in the scale and level of large-scale killing of civilians. That these types of events are associated with spikes in violence indicates that strategic concerns-retaining power, defeating enemies in wartime, responding to real and perceived threats-are a key dimension of the onset of atrocities.

\section{Triggers of Atrocity in Policy Discourse}

The concept of "triggers" is one of the most commonly used terms, within policy communities, to convey an event that signals the start of an atrocity. In his 2013 report on the Responsibility to Protect, the Secretary General referred to "triggers or drivers that create a permissive environment or engender a rapid escalation of tensions." The report in turn elaborated a number of specific triggers, including a non-constitutional change of government; events that spill over from a neighbor-

\footnotetext{
${ }^{3}$ For a discussion of elite decision-making in atrocity situations, see Straus (2015).

${ }^{4}$ Most forcefully articulated in Valentino (2004).
}

ing country, including armed hostilities or mass displacement; internal uprisings or unrest; the assassination of symbolic personalities; security vacuums following the removal of security forces from an area; and contests for power, such as elections when parties are factionalized along ethnic lines or where the electoral process lacks transparency" (UNSG, 2013, p. 6).

The 2008 report of the Genocide Prevention Task Force, a US-based civil society effort to stimulate better policy on genocide prevention, references "triggers that can tip a high-risk environment into crisis." It identifies such triggers to be unstable, unfair, or unduly postponed elections; high-profile assassinations; battlefield victories; and environmental conditions such as drought (GPTF, 2008, p. 37).

Lastly, the updated United Nations Framework for Analysis for Atrocity Crimes, which was released by the joint office of the Special Adviser on the Prevention of Genocide and the Special Adviser on Responsibility to Protect, refers to triggering factors as "events or circumstances that, even if seemingly unrelated to atrocity crimes, may seriously exacerbate existing conditions or may spark their onset." The Framework in turn elaborates 12 indicators of triggering factors, including the sudden deployment of security forces or start of armed conflict; spillover of armed conflicts or "serious tensions in neighboring countries"; actions taken by the international community perceived as threatening to a state's sovereignty; abrupt or irregular regime changes; attacks against the life or liberty of leaders or other serious acts of violence; incitement through propaganda; census and elections; sudden economic changes; discovery of natural resources; and commemoration events of past crimes (United Nations Office on Genocide Prevention and the Responsibility to Protect, 2014, p. 17).

Taken together, some of the key policy documents suggest two points. First, the concept of triggers indicates a change in circumstances but beyond that the concept remains imprecise. The Secretary General's report speaks of a "rapid escalation of tensions," the Task Force of "tip[ping] a high-risk environment into crisis," and the Framework for Analysis of "exacerbate[ing] existing conditions or [sparking] their onset." Second, the list of different possible triggers suggests a very wide range of events or occurrences that would cause an increase in violence. That large range would suggest that there are not really specific types of events that matter specifically for atrocities. Between these reports, triggers can be everything from economic crises, to environmental changes, to elections, to actions in the international community, to assassination and war. Both of these dimensions - a widely used but underspecified concept and a very expansive set of events that would qualify as triggers of atrocitysuggest a need for greater analytical attention to the subject. 


\section{Conceptualization, Research Questions, and a Provisional Definition of Triggers}

Turning to the academic literature, there is less explicit conceptualization and theorization of triggers of genocide or triggers of atrocities. That said, there are cognate terms that offer insight into any analysis of triggers of atrocities. One potential analogous concept in the academic literature is that of an "event." For example, sociologist William Sewell writes in a wellknown essay of an "historical event" that "changes the course of history" (Sewell, 1996, p. 842). Such events accelerate change and have the potential to transform relationships and structures, he argues (Sewell, 1996). Sewell's main example is the taking of the Bastille in France in 1789, an event that was a key turning point that led to the French Revolution. Sewell's focus is less that of an event that triggers violence and atrocity. However, his conceptualization of an event that accelerates change and has the potential to turn subsequent actions and events in a particular direction is useful for conceptualizing a "trigger" of atrocity.

Substantively closer to the subject of atrocity, Donald Horowitz writes in his book on deadly ethnic riots of "precipitating events." Horowitz defines a precipitating event as "an act, event, or train of acts and events, antecedent but reasonably proximate in time and place to the outbreak of violence and casually related thereto" (Horowitz, 2001, p. 269).

Horowitz is not writing specifically about atrocities; his work here is on "deadly ethnic riots." Yet his conceptualization offers several useful insights. First is the idea of "precipitation," which conveys the sense that an event draws in energy from the environment. An event actualizes tensions and emotions that are already present in a particular setting and in turn funnels that tension and emotion in a particular direction. The event itself matters, but the event cannot be separated from the environment and the underlying conditions in which it occurs. The appropriate metaphor is that of a "spark" or an "igniter," in the sense that the event unleashes force, but where the environment and the underlying conditions are analogous to the fuel.

Second is the idea, like Sewell, that a precipitating event has a causal effect on the outcome of interest. By implication, without that specific act, event, or chain of events occurring, the violence that followed would not have happened or would not have happened in the way that it did.

These various claims may be expanded and translated into research questions that contribute to a research agenda on triggers of atrocity. The first key question is how much does the context, or underlying conditions, matter versus how much does the specific event matter when assessing why atrocities begin?

It is unlikely that a specific type of event will uniquely be responsible for igniting atrocities. That is the case because the same or very similar types of events take on quite different meaning and significance in different contexts. Consider the case of a presidential assassination. In 1993, Tutsi soldiers assassinated Burundi's first democratically elected, Hutu president. His assassination sparked violence against Tutsis in rural Burundi, which in turn sparked reprisals from the Tutsi-led army, which in turn spiraled into a long, devastating, atrocity-laden civil war. Less than a year later, the Burundian Hutu president was killed when the plane, in which he and the Rwandan president were traveling, was shot down over Kigali, the Rwandan capital. In Burundi, the new president's death had little observable effect in terms of triggering atrocities. In Rwanda, the shooting down of the plane was the catalytic event that unleashed the genocide. What explains this variation in the effect of the different assassinations in the same country or between countries?

Consider another, relatively recent example. In Israel and Palestine, the kidnapping and murder of three Israeli students in 2014 prompted Israel to conduct military raids inside of Hamas-controlled territory in the Gaza Strip, which in turn prompted Hamas in Gaza to launch missile strikes into Israel, which prompted Israel to launch more military strikes, and then the violence spiraled. However, the kidnapping and murder of a few students (or other civilians) in other conflicts rarely has such a triggering effect.

Another example is that of a disputed election. It is fair to say that in many countries that are experiencing transitions to democracy or that can be characterized as semi-authoritarian there are frequently doubts about the credibility of an announced election result. In some circumstances, the announcement of an apparently fraudulent election may spark riots and protest, which in turn will prompt security forces to repress those movements. That was the case in Kenya in 2007, Iran in 2009, and Côte d'Ivoire in 2010. However, in other cases, the announcement of an apparently fraudulent result does not have the same effect. The question is why.

One hypothesis is that the underlying conditionsthe events and developments that precede the event as well as the levels of tensions, fears, and uncertainty in the environment-shape the significance of the triggering event in question. What mattered in Rwanda was the extensive deterioration in the political and military environment that preceded the president's assassination. What mattered in Israel and Palestine was the ratcheting up of tensions prior to the kidnappings. What happened in Kenya were the land-related disputes that preceded and were at stake in the elections. If the context matters, then from an analytical perspective, it is important to ask how much analytical weight should be given to the "triggering event" per se.

Another hypothesis is that the event's characteristics matter. If the event lines up with the contours of 
the underlying conflict, then the event will have greater impact. Consider the case of Burundi. In 1993, the assassination of the Hutu president was interpreted as evidence that the Tutsi elite would not allow Hutus to rule. The assassination thus signified to Burundian Hutu elites and ordinary civilians that Tutsis would not truly relinquish power, despite the democratic process. The symbolic and political significance of the event was great. By contrast, in 1994, the Burundi president who was killed was not the main target of the assassination. The main target was the Rwandan president. Thus, the 1994 assassination carried limited political significance in Burundi. It did not fit into the story of the political and military struggle in the country.

By the same token, consider the case of southern Kyrgyzstan in June 2010. Most accounts claim that a dispute in a bar in the city of Osh between ethnic Kyrgyzs and ethnic Uzbeks quickly escalated into generalized fighting between civilians associated with both ethnic groups. The bar dispute followed the so-called "tulip revolution" in Kyrgyzstan and rising tensions between Uzbeks and Kyrgzs in different parts of the country. The context clearly mattered, and in the case of Osh the very local dispute resonated and fit into the contours of the broader political dispute. Indeed, most bar disputes and fights do not escalate into inter-ethnic violence that leaves hundreds dead, as was the case in Osh.

A second key question concerns a tension between intentionality, planning, and triggering events. In the way that Sewell and Horowitz conceptualize events, the idea is that events have some causal power to change the course of history. Context matters in their accounts but so do the events themselves. Events have independent causal power. They crystallize energy and emotion and present a new beginning to a situation. That idea, however, can downplay the role of individual or collective planning before the trigger and decisionmaking after or during it. The idea of a powerful triggering event suggests that the trigger itself is what prompts individuals to act. By contrast, a framework that emphasizes planning and intentionality-which is generally how analysts interpret atrocity situationssuggests that violence was envisioned well before the triggering event itself. In this latter interpretation, the "trigger" is largely epiphenomenal; it does not have causal significance. A trigger may explain the timing but in this framework the trigger is primarily the excuse for starting violence, while the real reasons for the violence have to do with elite planning well before the triggering event itself.

If analysts take the causal power of triggers seriously, there are arguably two primary ways to conceptualize such independent effects. One is to conceptualize triggers as events that in and of themselves are so powerful that they crystalize emotions and in and of themselves prompt individuals or collectives to commit large-scale violence. In this view, the atrocity is some- what "spontaneous," an unforeseen reaction to a violation or transgression of such magnitude as to cause people to commit the unthinkable. To some extent, this is the perpetrators' alibi: the violence was unplanned; someone or something else caused them to act spontaneously. A total absence of planning and intentionality cuts against an atrocity framework, which emphasizes perpetrator responsibility for committing large-scale violence.

A more subtle interpretation recognizes that the events themselves matter but the key is how influential actors manipulate and use events. For example, in his study of violent riots in India, Paul Brass emphasizes that local actors transform symbolically significant incidents into what he calls "categorical events" that reflect broader, society-level contestation and conflict. Influential individuals encourage others to see an incident in a particular way that resonates with a broader dispute or tension; there are, in short, interests behind how and why different events taken on meaning (Brass, 1998, p. 27). The force of Brass's analysis, as it pertains to a discussion of triggers of atrocity, is to place the emphasis on elite response to events that have the potential to change perceptions. Here the events present a kind of elite opportunity. There is planning and intentionality but not necessarily before the event. The event has causal impact; it is the start to a new situation, in that sense a "trigger." But what matters is how elites respond. Elite agency matters. This view is consistent with an atrocity framework. It is a softer, more dynamic understanding of planning than one that views atrocities as planned out well in advance. It accepts that there is perpetrator responsibility but also recognizes how, in some cases, the atrocities themselves were not foreseen or at least foreseen in the way that they were carried out. The specific triggering event, which may not have been anticipated, is part of the causal chain.

Consider again the question of the assassination of Juvénal Habyarimana, the former president of Rwanda. Few would contest the idea that the event triggered the genocide in the sense that the assassination marked the beginning of a new period of highly elevated violence. However, many who have studied or prosecuted the genocide claim that the genocide was planned and prepared well before the execution of the president. Others, however, claim that the assassination itself had an independent effect on the dynamics in Rwanda at that time. In the first version-triggers as epiphenomenal-the genocide was planned well in advance; the trigger had little to no causal power except to explain the timing. In the second version, a strong interpretation of the power of triggers downplays the role of planning and intentionality. The view emphasizes the power of unforeseen events to change how people act and to change the dynamics of atrocity. This is the perpetrator alibi: the assassination "caused" a 
spontaneous reaction that led to genocide. A third way, as per Brass, is to recognize that the assassination was a significant event. It had the power to reorder perceptions and change strategic assessments. Yet the key issue is what influential elites did with the event. In the Rwandan case, Hutu hardliners associated with the former president and the ruling party established control of the state and ultimately orchestrated and encouraged the destruction of the Tutsi civilian population of Rwanda.

Consider again the case of Osh. In some interpretations of the violence, the key factor was less the bar dispute itself and more the local Kyrgz interests. Local Kyrgz actors took advantage of the dispute to oust large number of Uzbeks from the region, in turn capitalizing on their plight to gain commercial and political ground in the region. In this interpretation, the "trigger" was less powerful than political and economic opportunism and specifically the actions and intentions of a set of local actors. ${ }^{5}$ This interpretation is closest to the third way or elite manipulation model. The violence was not planned out well in advance, it seems, and a bar fight in and of itself was not so powerful as to trigger inter-ethnic clashes. What mattered is how elites responded and in this case manipulated the event in order to achieve what they wanted.

A third, related question to ask is how much to isolate a specific triggering event from a process of escalation. We might think of a triggering event as the "straw that broke the camel's back" in the sense that one event occurred along a chain of events that each contributed to an escalation of tension and violence. In the same vein, we might consider a trigger a "tipping point" or that which pushes a situation over the edge. In his study of the micro-dynamics of atrocities in Rwanda and Bosnia, Kluseman emphasizes that there is a period of tension, fear, polarization, and deterioration of relations that precedes significant violence (Klusemann, 2012). In that context, a precipitating incident can accelerate and crystalize those tensions and emotions, but the triggering incident cannot be separated from the deterioration and tension that preceded it. Again, context matters, and the event pushes the situation to a new level.

By contrast, we might consider an event along the lines of an earthquake, a "shock," in the sense that the event itself was so momentous and singular that on its own it reshaped the world around it. This question is, in some ways, a restatement of the two earlier questions. On the one hand, the question relates to the one about how much to weight the underlying conditions and tensions versus how much to weight the event itself. A straw-that-broke-the camel's-back approach is consistent with an approach that emphasizes the context and the conditions that precede the triggering

\footnotetext{
${ }^{5}$ For this interpretation, see ICG (2010).
}

event itself. By contrast, an earthquake approach would downplay context and conditions, emphasizing the power of the event itself to escalate violence. Similarly, the straw-that-broke-the camel's-back approach is consistent with a view that triggers are largely epiphenomenal except in the sense that they explain timing. A shock approach is more consistent with the perpetrators' alibi. Both views are potentially consistent with the elite manipulation story.

Consider again the cases under discussion so far. In Burundi in 1993 and in Rwanda in 1994, there were actions that preceded (and followed) the presidential assassinations that were critical for how events unfolded after the assassinations. Even though the presidential assassinations were momentous, a straw-that-brokethe-camel's-back approach would see the assassinations as part of a causal chain. By contrast, an earthquake approach would see the assassinations as so momentous as to change in a radical sense the political and strategic environments. In Israel and Palestine, the kidnapping and murder of the Jewish students was arguably one event in a spiral of violence; the kidnapping per se was not akin to an earthquake but is what tipped the situation into one that created a new period of violence. Similarly, in Kyrgyzstan, the violence in June 2010 in Osh followed violence in another city in May 2010 and the ousting of the president in April of that year. As Horowitz suggests, in many cases, it might be better to consider a chain of events and a chain of escalation rather than a specific single event per se.

These reflections prompt a fourth question, which concerns magnitude. Triggers vary by type and by magnitude. Is there a specific type of event or occurrence that typically initiates a new, elevated period of violence? Are those types momentous in some way? In some cases, triggers have dramatic national implications. A coup, an assassination, or an announcement of an illegitimate election result has national implications. Those occurrences have ramifications for a society. By contrast, some triggers are very local. A fight may start in a bar. Police may raid a neighborhood. A mosque may be desecrated. A fire may start. Those more local events may, in certain contexts, usher in a period of violence that may grow well beyond the locality where the initial provocation took place. The key question here is: which triggering events have the greatest magnitude in the sense of igniting an atrocity? We can hypothesize that events of greater symbolic, political, or military significance are likely to have a greater precipitant or catalytic effect.

To summarize the discussion, when considering the question of "triggers of atrocity," there are several questions to consider, including:

- How to define a trigger from an academic perspective;

- How much to weight the power of the event (or 
set of events) as opposed to the context and conditions in which the event or events occur;

- How much to weight the power of the trigger itself as opposed to the decision-making and planning before or after the triggering event;

- Whether to think of triggers as part of a chain of escalation or as having specific significance in and of themselves;

- How triggers vary by magnitude and characteristics.

These are all questions to be answered through empirical analysis.

As an initial working definition, I would define triggers of atrocity as "an event or chain of events that initiate a sharp escalation in atrocity violence."

The definition is parsimonious and flexible. The definition is agnostic on the four questions outlined in this section. The definition does not make a claim about context, intentionality, the process of escalation, or magnitude. Each of those areas deserves empirical analysis. This definition leaves room for the importance of context-triggers may take on meaning and significance in certain conditions. The definition leaves room for the idea that triggers are not necessarily one-off events, but may be part of a chain of events. We might hypothesize that triggers will trigger violence only if they have some significance in a political, military, social, or symbolic way but that claim is not inherent to the definition.

The definition implies that some events have the power to catalyze decision-makers or ordinary citizens to commit atrocities or levels of atrocities that they had not previously taken and many not have planned to take. The definition thus implies that triggers have independent causal power. That is, they change the dynamics of atrocity; counterfactually, then, without such events, the atrocity would not happen; would not happen when it did; or would not happen in the way that it did. Triggering events are essential turning points in the overall trajectory of violence. It seems to me that such a claim is essential if analysts seek to isolate "triggers" as being significant to when and why genocide and other forms of atrocity occur. Otherwise, we might think of triggers simply as events that mark, but do not trigger or independently influence, events.

The proposed definition is not a major departure from the conceptualization that Horowitz offers. Both definitions suggest that a trigger is an event or chain of events, proximate in time, and causally related to violence. The main differences are that a) the proposed definition applies to atrocities specifically (as opposed to deadly ethnic riots) and $b$ ) the proposed definition is a little more parsimonious than that of Horowitz. The main contribution is conceptual, rather than definitional, in the sense that this paper seeks to isolate and analyze key questions and hypotheses that pertain to an analysis of triggers.
It is worth noting is that not all atrocity cases will necessarily have clear triggers or sharp turns in escalation. There are "slow burn" situations in which famine, malnutrition, lack of medical care, or related factors may lead to high levels of civilian destruction. A case such as that of North Korea, in which there does not appear to be a clear trigger per se, but rather a more constant state of deprivation, repression, and persecution. Most atrocity cases do seem to have moments that signal a sharp spike in violence, but cases such as that of North Korea suggest that such spikes are not necessary for atrocities to occur.

\section{Empirical Analysis of Atrocity Triggers}

To probe some of the questions raised in the previous section, the paper analyzes a nonrandom sample of cases using qualitative methods. To date, there has been limited qualitative, comparative analysis of triggers of atrocity. In the quantitative literature on genocide, politicide, and mass killing, there has been analysis of "onset," which is different but akin to an analysis of triggers (Goldsmith et al., 2013; Harff, 2003; Ulfelder \& Valentino, 2008; Uzonyi, 2015). Many of these studies point to underlying conditions that increase the probability of atrocity in a country, such as infant mortality, a general period of instability, authoritarianism, exclusionary ideologies, prior genocides, or ethnic cleavages. But the studies also point to a number of plausible triggers: assassinations, leadership changes, election periods, military victories, and increases in defense spending, in particular.

That said, there is room for additional empirical analysis. First, there is no consensus in the quantitative literature on what triggers onset. Second, the quantitative literature is not explicitly focused on triggers per se but rather than measuring antecedent events that lead to crossing into a measure of onset (such as when civilian deaths reach a threshold of 1000 deaths per year). Third and most importantly, there is room for qualitative analysis that draws out some of the conceptual and theoretical issues discussed in the previous section. With its focus on mechanisms and with an ability to examine issues that are difficult to measure quantitatively across multiple countries, qualitative analysis is well suited towards this task. This section thus seeks to analyze a sample of atrocity cases with an eye towards developing a systematic analysis of triggers. It is a theory building exercise, as opposed to a theory testing one, built around a nonrandom sample of atrocity cases.

What then is the sample of atrocity cases? The concept of "atrocity" or "atrocity crimes" is generally defined in policy as including genocide, crimes against humanity, ethnic cleansing, and war crimes. That conceptualization would include a very large number of cases, given that there are no numerical thresholds for most of these crimes. As an exploratory empirical exer- 
cise, this paper sought a manageable number of cases ( $N=16)$ that nonetheless came from all world regions. In order not to bias which cases would be included in the universe of cases from which to sample, the paper draws on an established list of atrocity cases, in particular the mass killing case list in Jay Ulfelder and Ben Valentino's 2008 paper. This case list was supplemented with the post-electoral crisis from Kenya 2007-2008 in order to include a case that had a lower level of violence than many in the Ulfelder and Valentino case list and that was election related. From there, the sample of cases was purposively selected to conform to cases with which the author had some empirical familiarity. The analysis is broad-gauged, macro-level analysis based on the secondary literature.

The research questions asked for each case are: was there a sharp escalation in violence at an identifiable moment (i.e. was there a trigger, as defined above)? What prompted that sharp escalation in atrocity violence? To what extent did the context matter in driving the violence? To what extent did elite manipulation play a role? What kind of event or series of events triggered the escalation? Was the event a shock or a straw that broke the camel's back? The cases include:

- The Holocaust, 1941-1945

- Guatemala, 1960-1996

- Rwanda, 1963-1964

- Indonesia, 1965

- Nigeria, 1966-1970

- Burundi, 1972

- Ethiopia, 1974-1991

- The Khmer Rouge, 1975-1979

- India, anti-Sikh riots, 1984

- Bosnia, 1992-1995

- Burundi, 1993

- Rwanda, 1994

- The Democratic Republic of Congo, 1996-2004

- India, Gujarat, 2002

- Darfur, Sudan, 2003-2006

- Kenya 2007-2008

The analysis yields the following findings. In a general sense, in virtually all of these cases, there appears to be a point in time when an event or a development in a conflict initiates a sharp increase in violence. The concept of "triggers" is validated empirically, at least to an extent. In this sample, the primary triggers for atrocity are 1) significant changes in the strategic environment; 2) takeovers of territory with populations perceived to be associated with the enemy; 3) crackdowns on protest; and 4) violations of symbolically significant institutions.

\subsection{Significant Changes in the Strategic Environment}

The concept of changes in the strategic environment connotes the idea that some event or development occurs in which leaders in a state experience elevated threat. That event in turn initiates a sharp escalation in violence. In most cases, the state actors are engaged in armed conflict, though this is not necessarily the case. In general, the findings are consistent with strategic theories of the origins of mass atrocities (Ulfelder \& Valentino, 2008; Valentino, 2004).

The most common scenario is where non-state opponents of rulers in power launch a violent strike that signifies a direct and serious threat to the power of the ruling authorities. That threat in turn follows a period of growing strength on the part of the armed opponents or of growing weakness and vulnerability on the part of the ruling authorities. Concretely, such events are typically:

- Significant military advances by insurgent organizations;

- Coup or assassination attempts on heads of state or leading officials;

- Assassinations of heads of state or leading officials.

Of the 16 cases listed above, ten fit into this category, making this kind of trigger the most common scenario among the cases in this study. Guatemala was a long civil war but the peaks of violence that began in 1979 and the early 1980s followed significant gains by the Mayan insurgents in the Guatemalan highlands (Sullivan, 2012). In Rwanda, in 1963, the government launched large-scale violence against Tutsis after Tutsi exiles attacked the country and advanced on the capital. In Indonesia, the 1965 anti-Communist violence was triggered by a coup attempt, which military authorities blamed on the Communist party and which itself followed a weakened presidency (McGregor, 2009). In Nigeria, the anti-lbo violence in 1966 was triggered by a coup in which an lbo took power, and the 1967 and 1968 peaks of violence in the Biafran war were triggered by the start of that war and initial gains by the separatists. In Burundi in 1972, the anti-Hutu violence started after insurgents launched strikes against the Tutsi-dominated state. In Ethiopia, the violence spiked initially in response to political assassinations in the capital and later the violence spiked as the Tigrayan insurgents gained ground in the early 1980s. In India in 1984 , the anti-Sikh riots followed by the assassination of Prime Minister Indira Gandhi by a Sikh bodyguard. In Burundi 1993 and Rwanda 1994, as discussed above, the violence followed assassinations of heads of state. Finally, in Darfur, the violence against non-Arabs spiked after a major offensive by insurgent organizations in early 2003 , following growing strength on the part of the insurgents in that area.

These cases also provide answers for some of the questions in the previous section. First, political and military elites shaped the responses to the changes in 
the strategic environment. That is, the events themselves provided a catalyst and they crystallized fear and tension, but behind the events themselves political and military elites made decisions about how to take advantage of the changes in the environment. In so doing, they framed the events in particular ways. The Indonesian military and ruling party, for example, blamed the Communist party for the coup attempt. The Rwandan interim authorities blamed Tutsi rebels for the assassination of President Habyarimana; in turn, they encouraged and orchestrated attacks against the Tutsi civilian population. These observations support the elite manipulation hypothesis. Elites often transform incidents into triggering events or at least manipulate the interpretation of events in order to start a campaign of violence.

Second, the triggering events cannot be separated from their context. In each circumstance, the incident took place within a fragile political or military environment, and typically an environment in which relations between opposing groups had significantly deteriorated prior to the trigger.

Third, the characteristics and magnitude of the event mattered. In most cases, the incidents themselves had characteristics that resonated with the reigning political or social cleavage of the day. Moreover, all of these events signaled threats to the state and to the ruling order. They had significance. For example, the Communists were a growing force in Indonesia, and at least some members of the party were likely responsible for the coup attempt. A Communist takeover would have dealt a major blow to the ruling order (McGregor, 2009). In India, the assassination of Indira Gandhi-the president-followed earlier violence, significant tension between Sikh nationalist parties and the ruling Congress Party, and other lower-level assassinations (Tambiah, 1996). In Rwanda, the 1994 genocide followed three and a half years of civil war, growing deterioration and distrust between government and rebel forces, and lower-level violence; moreover, the Tutsiled rebels were plausibly responsible for the killing of President Habyarimana, again a president (Straus, 2006). In Darfur, the rebels launched an attack on governmentheld El Fasher and captured a colonel. That represented a direct threat. In Burundi in 1972, Hutu rebels launched attacks in the country at a time when officials worried that a Rwanda-style revolution could occur.

In sum, this cluster of events suggests that the trigger itself mattered but also that the event cannot be separated from the decision-making and actions of elites, from the context, and from the significance and characteristics of the event.

\subsection{Takeovers of Areas with Hostile Populations}

The second main scenario, which is arguably a subset of the first, is when political authorities or insurgent organizations make significant advances themselves and come to control new territory. In particular, when those authorities or organizations capture territory in which they plausibly face a threat from populations that they construe to be hostile or to be associated with their enemy, they in turn launch cleansing and repression campaigns to cement their power and territorial gains. In general, the finding is consistent with theories of atrocity that emphasize the importance of military takeovers (Uzonyi, 2015).

Of the case list above, the three main cases are the Holocaust, the 1975 violence in Cambodia, and the 1996-1997 violence in the Democratic Republic of Congo. In the case of the Holocaust, the Nazi state clearly had persecuted Jews and other groups in the 1930s. The state had experimented with euthanasia programs against so-called "unworthy" disabled citizens. But the sharp escalations in murderous violence against Jews took place in 1941 following, in particular, the German invasions of Poland and the Soviet Union. The territorial takeovers meant that the Nazis controlled territory with millions of Jews and, in the Soviet case, Communists. It was in that context that the general plans for deportation of Jews shifted toward the mass killing and eventual extermination of Jews (Browning \& Matthaus, 2004).

In the Cambodian example, the violence spiked after the Khmer Rouge took power in April 1975. Shortly after taking power, and riddled with internal rivalries, the Khmer Rouge executed large numbers of members of the former regime; they in turn evacuated the capital.

In the Congo, the violence spiked in late 2006 and early 2007 as Rwandan and AFDL forces gained control of territory in the eastern region. After sending hundreds of thousands of Hutu refugees back to Rwanda (and Burundi), the joint Rwandan/AFDL forces began attacking and liquidating large numbers of the remaining Hutu refugee population in Congo (UNHCHR, 2010).

As in the other cases, the changes in territory cannot be separated from the context and from the political and military decision-making. A strong anti-Jewish orientation animated the Nazi elite, and thus the way in which they framed their struggle shaped the response to the territorial gains in the Soviet Union and Poland. In Cambodia, the Khmer Rouge had a radical ideology that called for a total and complete revolution of society and state. In the Congo, the Rwandan military and political authorities believed that they were locked in an epic fight with Hutu forces, and two years before Hutu authorities had committed genocide. In these cases, the political and ideological context was essential to the significance that the territorial gains took, and the context was essential to the trajectory of violence that followed the territorial gains. In these cases, the decisions of elites mattered; leaders chose to cleanse when they acquired territory. At the same time, the territorial changes changed the dynamics on 
the ground-the territorial gains increased the perception of security risks or changed the calculations that elites made-in these cases triggering an escalation in violence.

\subsection{Crackdowns on Protest}

A less common, but nonetheless extant trigger for atrocity crimes is the repression of protest. In this scenario, political and security officials respond to organized and typically substantial street protest with a violent crackdown on the opposition. There are two main forms:

- In response to a contested election result;

- In response to a social movement looking to unseat a government.

The first scenario in this case is that electoral or political authorities announce the results of an election that the political opposition and some number of citizens find to be fraudulent. The opposition in turn organizes or encourages protests, which in turn prompt repression from security officials, which in turn leads to spiraling violence between supporters of the incumbents and supporters of the opposition. In the case list, the Kenyan violence in 2007-2008 is the main example; the contested elections in Iran and Côte d'Ivoire are out-of-sample examples of this type.

As with a significant change in the strategic environment and a military takeover of contested territory, the outcome of a national election has substantial implications. The results typically concern who controls the country. Much is at stake. Less well understood is why some contested election results provoke a spiral of violence while others protest fizzles, never materializes, or does not engender a violent state response. Initial research on post-electoral violence suggests that close elections matter and that confidence in electoral institutions matter. Where the opposition believes it should have won and where the opposition and citizens distrust the institutions that manage the electoral process, then they are more likely to turn to violence and street protest (Hafner-Burton, Hyde, \& Jablonski, 2014; Taylor, Pevehouse, \& Straus, 2015).

Another plausible scenario, which is not represented in the sample but which should be considered, is when political authorities repress violently a social movement that seeks some major change in the polity. An example would be when anti-government protests in Syria prompted violent crackdowns by state authorities.

\subsection{Symbolically Significant Violations}

The last category concerns triggers in which some symbolically significant violation takes place. In these cases, the violation signifies a transgression of some sort; there is a rupture that in turn sparks individuals, often with encouragement, to attack those who are seen to the authors of the violation. As in all the other cases, the violation takes on power, in the sense of mobilizing people to act, only in certain conditions and only with some explicit or tacit support for leaders or officials in a particular community.

The main example in the sample is the anti-Muslim violence in Gujarat in India in 2012. In that case, a train car caught fire, killing Hindu pilgrims who were returning from a pilgrimage. In the immediate aftermath, Hindu civilians and some Hindu political leaders blamed Muslims for setting fire to the train, and they proceeded to attack and kill hundreds and maybe thousands of Muslim civilians during the course of several weeks. ${ }^{6}$ The anti-Muslim took place in the context of worsening relations between Hindus and Muslims in the country, and the violence was endorsed by leading Hindu nationalist leaders in the country, notably the then Chief Minister (Nussbaum, 2007).

While there is only one case from the sample, similar kinds of triggers have occurred in India's past. Violence has taken place in relation to the religious site in Ayodhya. Hindus claim the site as the birthplace of the god Lord Ram, while Muslims had erected a mosque on the site. In 1992, a mob destroyed the mosque, triggering violence in different parts of the country that left several thousand dead.

In general, triggers of this type-that involved a symbolically significant violation-deserve some consideration as analyses of triggers go forward. These triggers seem to generate a smaller overall death toll than do changes in the strategic environment. The stakes matter, but in most cases the national government or a national organization is not directly driving the violence. As a result, the magnitude is less great than in those cases when states are committed to massacres to protect the state's interests.

\section{Conclusions}

To conclude, the concept of a "trigger" remains a useful one in the vocabulary of understanding and preventing mass atrocities. It seems clear that, in some contexts, certain events constitute turning points in the sharp escalation of violence. These turning points are appropriately conceptualized as "triggers" of atrocity. Overall, this paper has sought to push forward a research agenda on triggers by developing the concept, isolating key questions and hypotheses about triggers, and offering an exploratory empirical analysis of spikes in violence in a sample of atrocity cases.

Despite the endorsement of the concept of triggers

\footnotetext{
${ }^{6}$ An Indian government report claimed about 1000 civilians were killed (http://news.bbc.co.uk/2/hi/south_asia/4536199. stm). Nussbaum (2007) claims about 2000 Muslims were killed.
} 
in this paper, scholars and policymakers should remain cautious about how predictive or how causal triggers are. Empirically, the same category of event may lead to different outcomes. The paper's analysis yielded three findings that help to explain that variation. These findings in turn indicate that factors other than the event itself matter for why certain events have the power to initiate a sharp escalation of violence. First, context is critical. Triggers cannot be separated from the underlying conditions in which they take place. Second, the reactions and decisions of influential elites are central to whether or not events escalate into large-scale violence. Third, triggers of greater magnitude and triggers that graft onto the broader conflict will have greater significance. In particular, triggers that would seem to crystallize a direct threat to ruling authorities or that have broad, national implications seem to unleash the highest levels of violence. Certain events-battlefield advances, assassinations, assassination attempts, coups, coup attempts, territorial takeovers, protests, and symbolically significant violationscreate the raw material to usher in a new period of violence. They increase the risk of atrocity but atrocities are not inevitable after those events take place.

To deepen the understanding of escalation and triggers, much work remains. The empirical analysis in this paper is a start but the analysis remains necessarily superficial based on macro-comparative analysis. To understand why some events trigger atrocity (or do not), more micro-level analysis of key decisions and developments would be useful. In addition, while the paper yielded findings on some dimensions of triggers - such as context, elite manipulation, and types of triggers-other issues remain underspecified. Whether triggers are best conceptualized as shocks or straws that broke the camel's back (or both) is indeterminate in the analysis. To what extent does perpetrator capacity to commit violence matter and how does that capacity interact with triggers? Are there other important triggers not covered here? The paper's empirical analysis did not find that economic conditions or changes constituted triggers. But are there other cases where economic changes sharply escalated violence? The same is true for propaganda.

Lastly, how can triggers be anticipated and how can an understanding of triggers be translated into useful policy? Knowledgeable observers of specific cases should look to make educated predictions about whether one of the triggers isolated in this paper is likely to occur in a context that would result in a sharp escalation of atrocities. Would a battlefield gain, for example, have the effect of increasing threat perception? Would a battlefield gain mark some change in the overall dynamics of an armed conflict? Is a situation especially tense? Is the language of elites suggestive of a deep sense of foreboding and concern, such that a change in the strategic environment could lead them to change their tactics and use extreme violence? Finally, if, as this analysis suggests, triggers have power but their power depends on the ways in which elites interpret and use triggers, then that should create some space for external actors to influence those elites. ${ }^{7}$ Even if a specific event could signal a new level of threat, there is still some margin for maneuver for influencing elites who would make the decisions that would determine if violence sharply escalates.

\section{Acknowledgments}

This paper is based on a working paper completed for the United Nations Joint Office of the Special Advisers on the Prevention of Genocide and the Responsibility to Protect. The author would like to thank Simona Cruciani, Gillian Kitley, Hollie Nyseth Brehm, and Jennifer Welsh, as well as three anonymous reviewers, for comments and suggestions on previous drafts. The views herein are the author's own, and any mistakes the author's responsibility.

\section{Conflict of Interests}

The author declares no conflict of interests.

\section{References}

Bellamy, A. (2011). Mass atrocities and armed conflict: Links, distinctions, and implications for the responsibility to prevent. Muscatine, IA: Stanley Foundation.

Brass, P. (1998). Theft of an idol: Text and context in the representation of collective violence. Princeton: Princeton University Press.

Browning, C., \& Matthaus, J. (2004). The origins of the final solution: The evolution of Nazi Jewish policy, September 1939-1942. Lincoln/Jerusalem: University of Nebraska Press/Yad Vashem.

Goldsmith, B., \& Butcher, C., Semenovich, D., \& Sowmya, A. (2013). Forecasting the onset of genocide and politicide: Annual out-of-sample forecasts on a global dataset, 1988-2003. Journal of Peace Research, 50(4), 437-452.

Genocide Prevention Task Force (GPTF). (2008). Preventing genocide: A blueprint for U.S. policymakers. Washington, DC: United States Holocaust Memorial Museum, the American Academy of Diplomacy, and the United States Institute of Peace.

Hafner-Burton, E., Hyde, S., \& Jablonski, R. (2014).

\footnotetext{
7 Alex Bellamy (2011) makes a useful distinction between "structural" and "direct" prevention, with the former focused on long-term underlying conditions that increase the risk of atrocity and the latter focused on short-term actions that can be taken to stop or mitigate atrocities. A policy focus on triggers would relate primarily to direct prevention.
} 
When do governments resort to electoral violence? British Journal of Political Science, 44(1), 149-179.

Harff, B. (2003). No lessons learned from the holocaust? Assessing risks of genocide and political mass murder since 1955. American Political Science Review, 97(1), 57-73.

Horowitz, D. (2001). The deadly ethnic riot. Berkeley and Los Angeles: University of California Press.

International Crisis Group (ICG). (2010). The Pogroms in Kyrgyzstan (Asia Report No. 193). Brussels: International Crisis Group.

Klusemann, S. (2012). Massacres as process: A microsociological theory of internal patterns of mass atrocities. European Journal of Criminology, 9(5), 468-480.

McGregor, K. (2009). The Indonesian killings of 1965-1966. Online Encyclopedia of Mass Violence. Retrieved from http://www.massviolence.org/TheIndonesian-Killings-of-1965-1966.

Nussbaum, M. C. (2007). The clash within: Democracy, religious violence, and India's future. Cambridge, MA: Belknap/Harvard University Press.

Sewell, W. (1996). Historical events as transformations of structures: Inventing revolution at the Bastille. Theory and Society, 25, 841-881.

Straus, S. (2006). The order of genocide: Race, power, and war in Rwanda. Ithaca: Cornell University Press.

Straus, S. (2012). Retreating from the brink: Theorizing mass violence and the dynamics of restraint. Perspectives on Politics, 10(2), 343-362.

Straus, S. (2015). Making and unmaking nations: War, leadership, and genocide in modern Africa. Ithaca, NY: Cornell University Press.

Sullivan, C. (2012). Blood in the village: A local-level in- vestigation of state massacres. Conflict Management and Peace Science, 29(4), 373-396.

Tambiah, S. (1996). Leveling crowds: Ethnonationalist conflicts and collective violence in South Asia. Berkeley: University of California Press.

Taylor, C., Pevehouse, J., \& Straus, S. (2015). The perils of pluralism: Electoral violence and competitive authoritarianism in sub-Saharan violence. Unpublished manuscript.

Ulfelder, J., \& Valentino, B. (2008). Assessing the risks of state-sponsored mass killing. Washington, DC: Political Instability Task Force.

United Nations Office on Genocide Prevention and the Responsibility to Protect (UN). (2014). Framework of analysis for atrocity crimes: A tool for prevention. New York: UN.

United Nations High Commissioner for Human Rights (UNHCHR). 2010. Democratic Republic of Congo, 1993-2003: Report of the mapping exercise documenting the most serious violations of human rights and international humanitarian law committed within the territory of the Democratic Republic of the Congo between March 1993 and June 2003. Geneva: UNHCHR.

United Nations Secretary General (UNSG). (2013). Responsibility to protect: State responsibility and prevention (A/67/929-S/2013/399, July 9). New York: UN.

Uzonyi, G. (2015). Civil war victory and the onset of genocide and politicide. International Interactions, 41(2), 365-395.

Valentino, B. (2004). Final solutions: Mass killing and genocide in the twentieth century. Ithaca, NY: Cornell University Press.

\section{About the Author}

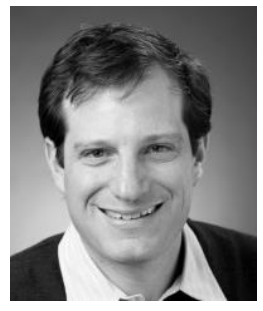

\section{Dr. Scott Straus}

Scott Straus is Professor of Political Science and International Studies at the University of Wisconsin, Madison. He is the author most recently of Making and Unmaking Nations: War, Leadership, and Genocide in Modern Africa (Cornell University Press, 2015) and Fundamentals of Genocide and Mass Atrocity Prevention (United States Holocaust Memorial Museum, forthcoming). 